\title{
COMPULSORY LICENSING IN OTHER COUNTRIES
}

\author{
BY P. J. FEDERICo*
}

\section{Great Britain}

The present law of Great Britain on the subject of compulsory licensing of patents ${ }^{1}$ is that of $1919{ }^{2}$ with the minor amendments of 1928 , I932, and $1938{ }^{3}$ This law represents a blending of two concepts and fulfills two different functions. One is the traditional requirement of working the invention within the country. The other is the regulation of the manner in which patents are used by the patentee. These are united in a theory of "abuse of monopoly rights" by Section 27 of the law, which represents a distinctly British contribution.

Section 27 declares the general principle upon which patents are granted in England: to encourage invention and to secure the working of new inventions on a commercial scale in the country without undue delay.

"B.S., Case Institute of Technology; A.M., George Washington University; LL.B., Washington College of Law. Member of the Bar of the District of Columbia. Examiner-in-Chief, United States Patent Office. Formerly editor of the Journal of the Patent Office Society.

1 "Compulsory working," "working clause," "revocation of patents for non-working," and similar phrases refer to the requirement or condition that a patent shall be forfeited, revoked, or void if there has been no commercial manufacture of the invention (working) in the country. The laws ordinarily specify a certain number of years after the grant of the patent within which the working must be commenced.

"Compulsory licensing" of patents refers to the condition or requirement that, upon some default or dereliction of the patentee, an administrative agency or court may grant, or compel the patentee to grant, a license under the patent. The default of the patentee may be a failure to work the invention, in which case compulsory licensing and revocation of the patent are two different consequences or penalties for the same failure. But, as will be seen, compulsory licenses may be ordered in other situations as well. The expression "compulsory licenses" is sometimes loosely used to indicate the proposal that patents be granted with the condition that anyone who wishes, without any default of the patentee, may obtain licenses under the patent. This is excluded from the meaning of phrase at this point.

${ }^{2}$ Patents and Designs Act, rgr9, 9 \& ro Geo. V, c. 8o.

${ }^{3}$ For a detailed history of the early British patent system, see Harold G. Fox, Monopolies AND Patents (1947), and J. Wyndham Hulme, The History of the Patent System Under the Prerogatives and at Common Law, I2 L. Q. Rev. I41-154 ( 1896$)$; On the Consideration of the Patent Grant, Past and Present, 13 L. Q. Rev. 313-318 (1897); The History of the Patent System Under the Prerogative and at Common Law: A Sequel, I6 L. Q. REv. 44-56 (1900); On the History of Patent Law in the Seventeenth and Eighteenth Centuries, x 8 L. Q. Rev. 28x-288 (r902). The texts, in French, of the patent statutes of foreign countries are printed in La Propriété Industrielle, the monthly publication of the Berne Bureau established by the International Convention, and in English in the periodical, Patent \& Trade-Mark Review. The Chartered Institute of Patent Agents, London, has published Patent Laws OF THE WORLD ( 2 vols. I9II), with supplements to date. There are a number of older collections.

'In most countries the majority of patents issued are granted to foreigners. The United States is low, granting only one-eighth of its patents to foreigners; Germany and Japan grant one-fourth, England and France one-half, and practically all of the other countries grant more than half of their patents to foreigners. The proportion is quite high in many countries: for example, 80 per cent in Holland and go per cent in Canada. These figures are for the period r930-1937. Hearings before the TNEC, Pt. 3 , 76th Cong., Ist Sess. Ir52 (1939). 
Subsection I of Section 27 states that if there has been an abuse of the monopoly rights under a patent any interested person may, at any time after three years from the grant of the patent, apply to the Comptroller (the head of the Patent Office) for relief.

Subsection 2 provides that the monopoly rights under a patent shall be deemed to have been abused in any of six specified circumstances.

The relief to be granted is specified in Subsections 3, 4, 5, 6, and 6A, which give the Comptroller the power to order the granting of licenses or to take other action there specified. Subsections 7 to I2 prescribe the procedure.

The first ground on which a compulsory license may be asked is the traditional one of failure to work the patented invention on a commercial scale in the country without a satisfactory reason for the non-working.

In discussing this ground it is necessary to consider the meaning of three phrases: "the patented invention"; "working on a commercial scale"; and "satisfactory reason for non-working."

"The patented invention" refers to the invention specifically described and claimed in the specification. If the patentee has claimed a wholly new machine he must manufacture the whole machine in the country. If he claims an improvement in a known machine, he need not necessarily manufacture the whole machine, but if the improvement is claimed in combination with a machine consisting of known parts it may be necessary to manufacture the improvement and put together the whole machine in the country. If the invention consists merely of a new combination of old and well-known elements it may be sufficient to assemble the machine in the country. Each case must be decided on its merits, considering the nature of the invention and exactly what is claimed in the patent, as well as other relevant circumstances.

Since the language of the section does not specify who must do the working, reliance may be placed upon manufacture by infringers in order to avoid the penalty for non-working.

A definition of "working on a commercial scale" is found in Section 93 of the Act. It is there stated that:

"Working on a commercial scale" means the manufacture of the article or the carrying on of the process described and claimed in a specification for a patent in or by means of a definite and substantial establishment or organisation, and on a scale which is adequate and reasonable under all the circumstances.

What constitutes a satisfactory reason for the non-working of the invention must be determined in each individual case. Insufficient time to work the invention is recognized as a reason in the Act itself. ${ }^{6}$

These statements are made on the basis of decisions concerning a similar phrase in the prior law. See note 3, supra.

- The following reasons for non-working are treated in decisions under the prior law:

Absence of demand and lack of capital are not acceptable excuses, if the patentec has failed to take reasonable steps to create the demand or to secure the necessary capital. 
The second ground for the grant of a compulsory license is specified as the prevention of the working of the invention in England by importing the patented article from abroad. ' The term "patented article" is defined in Subsection I3 as including not only an article which is patented, but also an article which is not patented but which is made by a patented process. This ground of compulsory license is likewise an expression of one of the traditional views with respect to working of the patent. The laws of some countries have contained provisions which canceled the patent or rendered it invalid if the patentee imported articles from abroad. This subsection applies not only if the patentee prevents the working of the invention in England by importation but also if by that means he makes the working in England unprofitable. The subsection also includes cases in which the patentee permits infringement by importation to continue unchecked to the detriment of commercial establishments in the country.

The third ground for granting compulsory licenses is that the demand for the patented article in the country is not being met to an adequate extent and on reasonable terms.

The requirement that the demand be adequately met may be considered as being merely an extension of, or as being involved in, the first ground. In fact, the first three grounds could very well have been grouped into one broader ground rather than being split into three separate statements, since they overlap to a considerable extent. $^{8}$

The requirement that the demand be met on reasonable terms is allied to the grounds which follow.

The fourth ground for the grant of compulsory licenses is that the patentee refuses to grant licenses upon reasonable terms, to the prejudice of the trade or industry of the country, and it is in the public interest that a license should be granted. This ground is, of course, the broadest one with respect to compulsory licensing, and

That manufacture in England would not be as profitable as manufacture abroad is not a satisfactory reason, but proof that there is no hope of profit, or that nothing but losses can be expected in view of the times, might be considered where foreign manufacture has not been favored.

Absence of special skill, experience, or equipment in the country has been held not an adequate reason for non-working, although this reason might be sufficient for securing more time to work the invention.

Infringement of a prior dominating patent may be acceptable as a reason for non-working.

7 The specific language is:

"(b) If the working of the invention within the United Kingdom on a commercial scale is being prevented or hindered by the importation from abroad of the patented article by the patentee or persons claiming under him, or by persons directly or indirectly purchasing from him, or by other persons against whom the patentee is not taking or has not taken any procecdings for infringement. ...."

${ }^{8}$ Four of the seven decisions under Section 27 involve primarily the failure to work the invention in England, including supplying the demand by importation: Intertype, Ltd, 43 Rep. Pat. Cas. (Reports of Patent, Design and Trade-Mark Cases) 305 (Comptroller, I926) (compulsory license granted); Cathro, 5I Rep. Pat. Cas. 75 (Comptroller, x933) (compulsory license granted in part only); McKechnie Bros. Ltd., $5 \mathrm{I}$ Rep. Pat. Cas. 44I (Comptroller, 1934) and $5 \mathrm{I}$ Rep. Pat. Cas. 46I (High Court, I934) (granted); Fabricmeter Company, Ltd., 53 Rep. Pat. Cas. 307 (Comptroller, 1936) (granted); cf. Ungarische Gummiwarenfabriks Actiengesellschaft, 50 Rep. Pat. Cas. 35 (Comptroller, 1932). 
gives the power to grant such licenses whenever it is considered necessary for the benefit of the country to do so. ${ }^{9}$

The fifth ground for granting compulsory licenses is the patentee's attaching to sales, leases, or licenses conditions which are prejudicial to the trade or industry of the country. ${ }^{10}$ The ground is in many respects analogous to Section 3 of the Clayton $A c t^{11}$ in this country, which makes unlawful sales or leases to which are attached certain specified conditions. The provision of the British statute is considerably broader since it applies not only to any conditions attached to sales or leases but also to conditions attached to licenses. However, these conditions are not made illegal as in the Clayton Act but are merely made the basis of compulsory licenses if the conditions are considered unfair or prejudicial.

The sixth ground for 'granting compulsory licenses is the use by the patentee of a patent for a process, involving the use of unpatented materials, for the purpose of asserting some control over the manufacture, use, or sale of the unpatented materials. ${ }^{12}$ This is the situation which has arisen in this country in a number of recent decisions ${ }^{13}$ and which has resulted in the holding that such attempts are illegal and render a patent unenforceable as long as the practice is continued.

The third to sixth grounds, which have just been mentioned, are in effect a means of regulating the manner in which a patentee uses his patent. They cover unreasonable refusal to grant licenses, and the making of unreasonable contracts with respect to patents and patented articles.

Subsection 3 of Section 27 specifies the powers of the Comptroller in the administration of the compulsory licensing provisions. If the Comptroller is satisfied that a case of abuse of the monopoly rights under a patent has been established, and if

The text is:

"(d) If, by reason of the refusal of the patentee to grant a license or licenses upon reasonable terms, the trade or industry of the United Kingdom or the trade of any person or class of persons trading in the United Kingdom, or the establishment of any new trade or industry in the United Kingdom, is prejudiced, and it is in the public interest that a license or licenses should be granted. . . ."

Two important cases have been brought under this fourth ground. Brownie Wireless Company, Ltd, 46 Rep. Pat. Cas. 457 (High Court, 1929), 45 T. L. R. 584 (1929) (compulsory license denied), and Loewe Radio Company, Ltd., 46 Rep. Pat. Cas. 479 (High Court, I929) (denied).

${ }^{10}$ The exact language is as follows:

"(e) If any trade or industry in the United Kingdom, or any person or class of persons engaged therein, is unfairly prejudiced by the conditions attached by the patentee, whether before or after the passing of the Act, to the purchase, hire, license, or use of the patented article, or to the using or working of the patent process. ..."

${ }_{11} 38$ STAT. 731 (I9x4), I5 U. S. C. $\$ I_{4}$ (I940).

12 The wording of the sixth ground in the act is:

"(f) If it is shown that the existence of the patent, being a patent for an invention relating to a process involving the use of materials not protected by the patent or for an invention relating to a substance produced by such a process, has been utilized by the patentec so as unfairly to prcjudice in the United Kingdom the manufacture, use or sale of any such materials. . .."

${ }^{13}$ Carbice Corp. v. American Patents Corp., 283 U. S. 27 (I93I); Leitch Mfg. Co. v. Barber Co., 302 U. S. 458 (1938); Morton Salt Co. v. G. S. Suppiger Co., 314 U. S. 488 (1942); B. B. Chemical Co. v. Ellis, 3 I4 U. S. 495 (I942); United States v. Univis Lens Co., 3 I6 U. S. 24 I (I942); Mercoid Corp. v. Mid-Continent Investment Co., 320 U. S. 66x (I943); Mercoid Corp. v. Minneapolis-Honeywell Regulator Co., 320 U. S. 680 (1943). 
he deems it expedient under the circumstances, he may issue an order in accordance with five specified provisions in Subsection 3.

The Comptroller may issue an order declaring that licenses under the patent are open to anyone who may apply. The terms and conditions of such licenses are specified by the Comptroller on application to him. The technical phrase used in this connection is that the Comptroller "may order the patent to be endorsed with the words "license of right." "The order declaring the patent open to licensing may be made notwithstanding any existing agreements by the patentee which purport to preclude such general granting of licenses. If such an order is made, existing licensees may apply to have their terms revised, or rather to exchange their licenses for a license ordered by the Comptroller. "Licenses of right" are also provided for in Section 24 of the British law, which will be discussed in detail later.

Secondly, the Comptroller may order the granting of a license to the particular applicant before him. This license is to be granted upon such terms as the Comptroller thinks expedient, and may prevent the licensee from importing into the country. The licensee is entitled to call upon the patentee to sue infringers or to sue infringers himself if the patentee refuses to do so. ${ }^{14}$

Third, the Comptroller may, under certain circumstances, order that an exclusive license be granted. The circumstances specified in the statute are that the invention cannot be worked on a commercial scale without the expenditure of capital, to raise which reliance upon the patent monopoly is necessary. Then the Comptroller may order that an exclusive license be granted to the applicant or any other person who is able and willing to provide such capital. Subsections 4,5 , and 6 specify various conditions for such an exclusive license. The license is ordinarily granted so as to exclude even the patentee himself. An existing licensee is to be preferred, but the order may revoke any preexisting license. The new licensee may be ordered to compensate the patentee or an existing licensee for development expenses. The exclusive compulsory license should ordinarily guarantee to the patentee a minimum yearly royalty. The exclusive license is also subject to subsequent revocation if the licensee fails to work the invention within the time specified in the order or if he fails to expend the amount of capital specified.

The fourth paragraph refers to the license which may be granted pursuant to the sixth ground for compulsory license. The Comptroller may order the granting of licenses to the applicant and to such of his customers as the Comptroller may think expedient.

The fifth paragraph provided that the Comptroller could also order the patent revoked if he were satisfied that the objectives of the section could not be obtained by the exercise of the preceding powers. No instances of petitions for revocation of patents on this ground have occurred since the Act of I9r9. This paragraph was deleted from the Act in 1938 , and replaced by the new Subsection $6 \mathrm{~A}$, which follows

${ }^{11}$ The subsection, $27(3)(d)$, refers to Section 24 for some guides in settling the terms of the license. 
the terms of the 1934 revision of the International Convention. ${ }^{15}$ Under this provision the patent cannot be revoked until at least two years from the grant of the first compulsory license.

The last paragraph of Section 27 (3) provides that the Comptroller may also dismiss the application if he is of the opinion that the objects of the section will thus be best obtained.

Subsections 7 to I2, inclusive, of Section 27 specify the procedure to be followed in seeking compulsory licenses. The application must set out the nature of the applicant's interest, the facts on which he bases his case, and the relief which he is seeking. The application must be accompanied by a statutory declaration (oath). The Comptroller then considers the matters alleged in the application and, if satisfied that a prima facie case is made out, he directs the service of copies upon the patentee or any other person having an interest in the patent, and also advertises the application in the Official Journal. The patentee or any person may oppose the granting of the license by filing a verified counter-statement or opposition setting forth the grounds upon which the application is opposed. The Comptroller may consider the statements filed and determine from them alone whether the application should be dismissed, or he may require the attendance before him of any of the parties for examination or cross-examination, and the production of books and documents, subject to due precautions against disclosure of information to rivals in trade. The decision of the Comptroller, called "order" in the statute, is subject to appeal to the courts, and in the appeal the Attorney General or counsel appointed by him is entitled to appear and be heard. The Comptroller may, if the parties interested consent or if the proceedings require prolonged examination of documents and investigation, order the proceedings or any questions of fact to be referred to an arbitrator agreed on by the parties or appointed by him. The award of the arbitrator is to be final if the parties consent, but otherwise is subject to the same appeal as the decision of the Comptroller himself. Costs may be awarded by the Comptroller. ${ }^{10}$

The order for the granting of the license may have the specific language of the license attached to it. A different section of the Act, $83 \mathrm{~A}$, provides that the order for the granting of a license shall operate as if it were embodied in a deed granting a license executed by all necessary parties, without prejudice to any other method of enforçing the order. ${ }^{17}$

In the twenty years from the passage of the Act in I9I9 to 1939, seventy-three applications for compulsory licenses under Section 27 were filed, an average of less than four a year. Of these applications, fifty were withdrawn and abandoned, and a few were dismissed on formal grounds, including the reason that the patent

\footnotetext{
${ }^{15}$ Sce Stephen Ladas, International Protection of Industrial Property (1930), and Emerson Stringham, Patent and Gebrauchsmuster in International Law (1935), for a history of the Convention.

${ }^{10}$ The decisions which have been cited in notes 8-10, supra, illustrate various factors in the procedure.

${ }^{17}$ The Cathro and McKechnie cases, supra, note 8, give the texts of licenses.
} 
had expired. Only sixteen applications ${ }^{18}$ went to hearing and decision; four were refused, two because no prima facie case was made out; and twelve were granted by the Comptroller, but on appeal he was reversed as to seven of these. The net result is that compulsory licenses were ordered in five applications over a period of twenty years.

The large proportion of withdrawn and abandoned applications probably includes many which were compromised by the parties. In fact, the Patent Office postpones hearings freely to induce settlements.

Several explanations may be offered for the small number of cases which are filed under compulsory-licensing or compulsory-working laws. One argument is that such laws are of little practical value; the need for them is small; the occasion for their application is infrequent; and the proportion of unused patents is not much less, if any, than without such laws. On the other hand, it is argued that the existence of such laws has a deterrent effect on the suppression of patents and prevents patentees from misusing their patents or insisting on unreasonable terms, and that these laws induce compromises between rival parties. ${ }^{19}$

\section{Canada}

In general the patent laws of the British dominions and colonies follow that of England with respect to compulsory licenses and compulsory working, although some have not yet adopted the latest revisions. Thus the law of Australia is similar to the British law as it stood prior to I9Ig, and a committee appointed to revise the patent statutes in 1937 recommended that the statute be revised in accordance with the British revisions. The laws of New Zealand and the Irish Free State are similar to the British Act of rgig.

The Canadian law (Sections $6_{5}$ to $7 x$ of the Patent Act) ${ }^{20}$ with respect to compulsory licensing is parallel to the present British law; in fact, the Canadian statute uses the exact language of the British statute throughout, except for the differences noted hereafter. The first difference is that in Canada the Attorney General as well as any person interested may apply to the Commissioner. Further, the Canadian statute does not contain provisions with respect to licenses of right. With respect to procedure the Canadian statute provides that the Commissioner may, with the approval of the Minister, refer the whole proceeding to the Exchequer Court of Canada, in which case the decision of the court is final; also any particular issue of

\footnotetext{
${ }^{28}$ Some of the sixteen applications were considered in groups since the patents related to the same subject matter and the same parties were involved. Actually, there were only seven distinct cases, and the decisions in all of these have been referred to in notes 8-10, supra.

${ }^{10}$ British writers are in the main satisfied with the statute and its operation, particularly as a deterrent. However, a recent committee studying the British patent law has recommended rephrasing and broadening several of the grounds on which a compulsory license may be obtained in order to avoid the narrow interpretation placed upon several phrases by the courts, and also adding other grounds. Second Interim Report of the Departmental Committee, Cmd. 6789 (H. M. Stationery Office, London, I946.)

${ }_{20}$ The Patent Act, 1935, 25-26 GEO. V, c. 32.
} 
fact may be referred to the court for its determination and report to the Commissioner.

The Canadian statute contains a section not found in the British law. This is Section 64, which provides that the Commissioner may at any time require a patentee, or his representative in Canada, or any person who has an interest in the patent, to supply the Commissioner with a statement as to whether the patented invention is being worked on a commercial scale in Canada, the place where it is worked, the names and addresses of the persons by whom it is being worked, and the reasons why it is not worked, if any. The failure to supply such a statement within sixty days is deemed to be an admission that the patented invention is not worked on a commercial scale in Canada.

The present Canadian statute was enacted in 1935 . Up to 1942, thirteen applications for compulsory licenses had been filed. Seven applications were withdrawn or abandoned. Decisions were published in five cases; in two licenses were granted, and in three denied.21

\section{GERMANY}

The provisions of the German Patent Act of 1936, Sections 15 (1) and $15(2)$, in regard to compulsory licensing and revocation, are as follows:

I5 (I). If the patentee refuses to allow the invention to be used by another person who offers to pay him an adequate compensation and to furnish security in respect thereof, then the latter shall be granted a license to use the invention [a compulsory license] if the Government declares the permission to be warranted for the purpose of guarding the interests of the public and if at least three years have elapsed since the grant of the patent has been published. The license may be limited or made dependent upon conditions.

I5 (2). As far as international agreements do not prevent it, a patent is to be revoked if the invention is carried out exclusively or mainly outside Germany. The revocation cannot be demanded until two years after the legal grant of a compulsory license and only if the Government declares that the interests of the public cannot be sufficiently served any longer by granting compulsory licenses; however, these reservations do not apply in the case of persons belonging to a foreign country which does not grant reciprocity in this respect. The assignment of the patent to another person shall be ineffective if its only purpose is to circumvent the revocation.

Sections 37 through 42 govern the procedure. An action to obtain a compulsory license is instituted by filing a petition in the patent office, stating the facts upon which it is based. The parties are heard, and the costs of the proceedings are charged against them. A direct appeal to the Supreme Court is allowed from the decision of the patent office.

If a prima facie case is made out and a declaration of urgency is furnished by the

${ }^{21}$ The three cases in which licenses were refused involved the same parties. Providence Machincry Co., Itd. v. Scott and Williams, Inc., I Can. Pat. Rep. 281, 289 (Commissioner of Patents, 1939). The two cases granting licenses are: The Celotex Corp., 2 Can. Pat. Rep. 26 (Commissioner of Patents, 1938, aff'd Exchequer Court, I939); E. H. Tate Co. v. Riley, 2 Can. Pat. Rep. 53 (Commissioner of Patents, I94I). 
Government, a preliminary license may be granted immediately, subject to the furnishing of security and the subsequent adjustment of damages if the license is not granted by the ultimate decision.

To obtain a compulsory license the petitioner must show that he has requested a license from the patentee, with a suitable offer of compensation and security, and that the license has been refused. The request for a license must be a bona fide one, and the compensation (royalty) and security offered sufficient in view of the nature and value of the invention and the interests and businesses of the respective parties. The refusal of the license may be either express or implied, as by failing to reply within a reasonable time or by a demand of such prohibitive terms as to amount to a refusal. The refusal must be unjustified. The request for a license may be made after filing the petition, but before decision. The petitioner must possess or have available the necessary capital and the necessary ability and skill to use the patented invention. The fact that the petitioner is an infringer is not a bar. It is also necessary to ascertain that it is in the interest of the public that a license be granted-perhaps the most important prerequisite. This question was determined after 1936 merely by the statement of the "government."22

The license which is granted is non-exclusive and may be subject to conditions or limitations; it is often limited to the use of the invention in the establishment of the licensee, or to particular devices, or to exporting only; and it may specify minimum sales prices. The fixing of a royalty appears to be a difficult matter. The royalty fixed has ranged generally from I per cent to ro per cent of the selling price in the case of a patented article, although it may be higher. A minimum royalty may be specified and security amounting to approximately the royalties for one year may be required. If the licensee should not use the invention, he would be subject to payment of the minimum royalties if any are specified. The licensee cannot grant sub-licenses, and the license cannot be transferred apart from the business. ${ }^{23}$

The number of actions for compulsory licenses instituted in Germany is somewhat greater than in England. During the eleven-year period from I924 to I934, there were 140 petitions under the law prior to the 1936 Act. During this same period, 87 were withdrawn, 44 refused, and I7 granted. Fourteen were granted from IgII to I925. Thus only a fraction over one license per year had been granted prior to the 1936 law. Since then the number of applications filed and granted has been somewhat higher. ${ }^{24}$

\section{The French Law}

France has not enacted a compulsory-licensing law. Article 32 of the patent law

22 This means the cabinet minister at the head of the department. His statement will govern all further action in the case. Klauer, The New German Patent Law, 18 J. PAT. OfF. Soc'y, $48 \mathrm{I}-492$ (1936).

${ }_{22}$ See commentaries on the German Patent Law: for example, Isav, Patengesetz (fifth ed. 1931); Krausje, Das Patengesetz (1936); Lutrer, Patengesetz (1928).

${ }^{24}$ The German patent office ceased functioning at the end of hostilities and has not yct resumed operation. Actions for compulsory licenses were abolished by decree in 1942 . 
of 1844 provides that the patentee who has not exploited his invention in France within two years from the grant of the patent, or who has ceased the working for a period of two years, shall be deprived of his rights, unless proper excuse for the inaction is shown. The text of this working provision has not been substantially revised since it was first enacted, except that the minimum period for beginning working has been changed to three years for citizens of countries which are members of the Convention.

By Article 34 of the French law any interested person may institute an action to revoke a patent. Such an action must be brought in the civil courts. By Article 37 the public minister must intervene for the revocation to be made absolute.

The number of actions instituted is not known, but appears to be comparatively small. Since the enactment of the law over a hundred years ago, there have been published a little over one hundred decisions of the courts in actions under it.

The statute uses the word "exploit," which has been interpreted as meaning actual manufacture. It is not necessary, however, that all modifications or variations, or all applications, of an invention be worked. Since the statute uses the words "the patentee who has not ...," the working must be by or for the patentee, or by his licensee; working by an infringer will not avoid forfeiture of the patent. The existence of a prior patent which would be infringed will justify non-working until after the prior patent has expired unless it, or a license under it, could be readily acquired on reasonable terms.

In I930 France ratified the Hague amendment to the Convention, which provided that a patent could not be revoked for non-working unless compulsory licenses were insufficient to eliminate the failure to use the invention. No compulsorylicensing law has been enacted in France, and there has been considerable difference of opinion as to whether or not revocation of patents for non-working has been abolished. Different views have been expressed by different courts. The difficulty has been met in some cases by a more lenient treatment of the excuses for failure to work the invention, and in others by holding that the patent could not be revoked. Various proposals have been made for revision of the French patent law by substituting compulsory licenses for revocation of the unexploited patent.

\section{OTHER Countries}

Compulsory-licensing laws in general have replaced laws providing for revocation of patents for non-working, mainly due to successive revisions of the International Convention for the Protection of Industrial Property. The latest revision, that of London in 1934, provides that no compulsory license can be demanded until three years after the grant of the patent and unless the patentee fails to produce adequate excuses. The patent cannot be revoked unless (I) a compulsory license has been issued, (2) the granting of compulsory licenses is insufficient to prevent abuses, and (3) the action to revoke the patent is instituted at least two years after the grant of 
the first compulsory license. These conditions obviously reduce the revocation of patents for non-working practically to the vanishing point.

No other country has such well-developed laws as those of Great Britain and Canada, and the laws of countries which are parties to the International Convention are in most instances restricted as required by the Convention. The provisions vary considerably. In most, non-working of the invention in the country is the sole ground mentioned. Some laws provide for the grant of a compulsory license to the owner of a dependent (improvement) patent of commercial importance, but the owner of the first patent is then also entitled to a license under the second patent. ${ }^{25}$

A number of countries still have compulsory-working laws without any compulsory-licensing enactments. ${ }^{26}$ The period within which the invention must be worked is usually two years, although one, three, four, and five years, and other periods, are found. Interruption of working for similar periods also has the same results. While working usually means actual manufacture in the country, this is not the case in many of the countries in this group. The working or exploitation may be purely nominal, as by advertising or by exhibition of the invention, while in a few the working in other countries may suffice. A few countries do not have any working requirement or other provision of a similar nature in their patent laws. ${ }^{27}$

Offers to Grant Licenses-"License of Rrght"

In many countries which have compulsory-working laws, particularly the smaller countries and those of less industrial importance, the requirement to work the invention in the country may be satisfied in a purely nominal manner-even by merely advertising an offer to grant licenses.

In I9r9, England introduced a provision to encourage and regulate public offers to grant licenses. Section 24 of the British statute provides that a patentee may, at any time after the patent is sealed, apply to the Comptroller to have his patent endorsed with the words "licenses of right." When the patent is so endorsed certain results follow.

The first and most important result is that any person is thereafter entitled to a license under the patent as a matter of right. The terms of the license may be settled by agreement of the parties, but if an agreement cannot be reached, the terms may be settled by the Comptroller on application by either party.

The statute directs the Comptroller, in settling the terms of any license, to be guided by several considerations. First, he must, on the one hand, endeavor to secure the widest possible use of the invention in the United Kingdom consistent

${ }^{25}$ No attempt will be made to set forth the patent laws of all countries with compulsory-licensing or compulsory-working provisions. Among those with compulsory-working and compulsory-licensing provisions are: Austria, Belgium, Bolivia, Brazil, Bulgaria, Cuba, Czechoslovakia, Denmark, Finland, Greece, Guatemala, Holland, Hungary, Iceland, Italy, Japan, Luxemburg, Mexico, Norway, Paraguay, Poland, Russia, Spain, Sweden, Switzerland, Uraguay, and Yugoslavia.

${ }^{20}$ Argentina (1864), Costa Rica (1896), Dominican Republic (I9II), Ecuador (1928), Honduras (1919), Iraq (I935), Iran (I93I), Nicaragua (1899, I926), Panama (I908), Peru (I869, I914), Portugal (1894), Rumania (I906), Turkey (I880), Venezuela (I927).

27 These are: Chile and Colombia (working laws eliminated in 1925); Haiti; Lithuania; Salvador (but a patent may be expropriated). 
with the patentee's deriving a reasonable advantage from his patent. Second, on the other hand, he must endeavor to secure to the patentee the maximum advantage consistent with the invention's being worked by the licensee at a reasonable profit in the country. Third, the Comptroller must also endeavor to secure equality of advantage among several licensees, and for this purpose may reduce the royalties in any previously granted license. The Comptroller must take into account any work done or outlay incurred by any previous licensee in developing the invention on a commercial scale.

The license may preclude the licensee from importing into the country. The licensee is entitled to call upon the patentee to proceed against infringers, and if the patentee refuses or neglects to do so, the licensee may sue in his own name, making the patentee a party defendant.

The second result which follows from the endorsement of a patent with the words "licenses of right" is that no injunction can be obtained against an infringer who is ready and willing to take a license upon terms to be settled by the Comptroller, and the damages recoverable from such infringer cannot exceed twice the amount he would have had to pay under a license. This provision, however, does not apply when the infringement consists in the importation of infringing goods.

The third result is that the annual fees or taxes payable on the patent are reduced by one-half.

If there is a patent of addition, the endorsement of either it or of the main patent carries with it the endorsement of the other.

When a request to endorse a patent is made, it is advertised in the Official Journal, and the Comptroller must satisfy himself that the patentee is not precluded by an existing contract from making the request. A preexisting non-exclusive license is not a bar. Any person may oppose the request if it is contrary to a contract in which he is interested, and if the allegation is true the request will be refused, or the endorsement will be cancelled if already made.

When the endorsement is made it is entered on the register of patents and published in the Official Journal; it may also be published in such other manner as may seem desirable for the purpose of bringing the invention to the notice of manufacturers.

The patentee may apply to have the endorsement cancelled on payment of the unpaid fees or taxes. Existing licensees must consent to the cancellation, and any person may oppose an application for cancellation. ${ }^{28}$

Any decision of the Comptroller may be appealed to the courts.

During the nineteen years from 192I to 1939, the number of patents endorsed averaged 690 per year, which is about 4 per cent of the average number of patents granted each year. During this same period the number of applications to cancel endorsements averaged seventeen per year. There were twenty petitions to settle the terms of licenses during this period. The disposition of these petitions is in-

${ }^{28}$ The only decision of the Comptroller under Section 24 appears to have been on an application to cancel an endorsement, Serenyi's Patent, 55 Rep. Pat. Cas. 228 (Comptroller, 1938), which was granted. 
teresting: one was suspended at the request of the parties the same year it was filed; five were withdrawn or abandoned the second year after they were filed; one was withdrawn the fourth year after it was filed; one was pending during the fifth year after it was filed, when the patent expired; seven were still pending the sixth year. The ultimate disposition of these and five others is not stated in the reports. ${ }^{29}$

There is some difference of opinion as to the value of the "license of right." On the one hand the procedure gives a public and official record of patents which the owners are willing to license to anyone; it gives the services of a government official and of the courts in settling disputes as to terms; and it enables a patentee to escape part of a heavy burden of fees or taxes. On the other hand it is said that only patentees who are unable to license their patents, or to utilize them in any other way, request the endorsement.

The German patent law of 1936 contains a section similar to the section of the British patent law just described. According to Section I4 of the German law, any applicant or patentee may file in the patent office a declaration that he is willing to permit anyone to use the invention in return for adequate compensation, whereupon the annual fees or taxes (which are much higher than in England) are reduced by half. The declaration is irrevocable, and cannot be made if an exclusive license is recorded. Any person thereafter intending to use the invention must give notice of his intention to the patentee, stating the manner in which the invention is to be used. He is then entitled to use the invention in the manner indicated, and must account to the patentee quarterly and pay the compensation. On default in meeting this obligation the patentee can forbid any further use of the invention. The compensation, on written petition of either party, is fixed by the patent office without right of appeal. After one year from the fixing of the compensation either party may petition for revision if conditions have arisen or become known which make the established royalty unsuitable. During the four years 1937 to 1940 an average of 860 declarations per year were published, which is almost 6 per cent of the average annual number of patents granted in those years.

\section{General Compulsory Licensing}

Thus far, the term "compulsory licensing" has been limited to the granting of a license by a government agency on some default or dereliction of the patentee. When the public interest is considered, the failure to grant licenses itself may constitute a default or dereliction, and in this respect the definition may be somewhat too narrow.

In recent discussions in this country, the proposal has been made that all future patents be made available for use by anyone who may desire their use and who is willing to pay a fair price for the privilege. This may be called "general compulsory licensing" as contrasted with compulsory licensing as here considered, which has been called "restricted compulsory licensing." "General compulsory licensing"

so The British statute was adopted in Australia, New Zealand, and the Irish Free State, but not, it should be noted, in Canada. Greece in 1920 and Bulgaria in $192 x$ adopted simple provisions for the declaration and publication of offers to grant licenses. 
would result in a patent which is not a patent in the sense that the concept of patents for inventions has been hitherto considered, that is, the grant of the exclusive right to an invention.

While such pseudo-patents, so to speak, are not granted by any country, there are a number of situations in which, for reasons of paramount public interest, the inventor is not granted, or is deprived of, the exclusive right to his invention, either generally or for certain purposes. The principal examples are the use of an invention by the government, the case where a particular patent is expropriated or declared in the nature of a public utility by some governmental procedure, and the case where a particular class of inventions is set aside by statute as being peculiarly affected with such a public interest that special regulations are required.

The laws of practically all countries, although differing in form, provide that any patented invention may be used by the government without the consent of the patentee, on payment of compensation. The war emergency legislation of the United States, Great Britain, and other countries, both in the first and in the second World Wars, has also provided for the general granting of licenses under enemyowned patents as well as for the seizure of such patents.

A number of countries have statutory provisions for the expropriation or withdrawal of patents when such action is considered necessary in the public interest or for the public welfare. By this is meant not expropriation for the use of the government, since use by the government may be otherwise provided for, but expropriation for general use. The right of the patentee to compensation is always protected. The expropriation is ordinarily accomplished by the "government" or an administrative body, but the matter of compensation may be taken to the courts in the event of disagreement. Some of the statutes do not specify any procedure, others refer to general laws relating to expropriation of property by the government, while a few contain elaborate details. Examples of the application of these laws are not available. In all likelihood they are seldom utilized.

In Europe such laws are found in Austria, Bulgaria, Denmark, Finland, Greece, Holland, Italy, Norway, Poland, Russia, Spain, Sweden, Switzerland, and Yugoslavia; in Latin America in Bolivia, Brazil, Mexico, and Salvador. In some of these countries it is not clear whether use of the invention by the state only is intended.

The Swedish law of 1884 provides that if the King considers it necessary that a patented invention shall be open to the free use of the public, the patent may be expropriated on payment of full compensation to the patentee. If the compensation cannot be agreed upon, it is determined by a special jury according to the procedure for condemning land required for public purposes.

The Danish law of 1894 and 1936 states that, when the public interest demands, a law may be enacted declaring a patent lapsed so that the invention becomes available for free use by the public; compensation is to be paid by the state, and in the event of disagreement the amount is determined by a board of arbitrators appointed as specified in the patent law. In Spain also the patent can be expropriated by a special law, which also fixes the compensation. 
The law of Greece of 1920 provides that the Council of Ministers may decide, and the King by decree declare, that a particular patented invention is a public utility, and thereafter the patentee must grant licenses, or licenses may be granted by a Minister, subject to compensation to be paid by the licensees. In default of agreement the compensation is fixed by the Ministry or by the courts. The annual taxes to be paid by the patentee are in this case reduced to half. The Bulgarian law of Igar is to the same effect.

Some statutes have made specific provision for the general granting of licenses in the food and drug field. A provision was added to the British statute in I9r9 (Section $3^{8 \mathrm{~A}}$ (3) ) that, in the case of any patent for an invention intended or capable of being used for the preparation or production of food or medicine, the Comptroller may grant to any applicant a license limited to the use of the invention for food or medicine. The license need not be granted if good reason to the contrary is shown. In settling the terms of the license the Comptroller is directed to consider the desirability of making the food or medicine available to the public at the lowest possible price consistent with giving the inventor due reward for the research leading to the invention. The ruling of the Comptroller is subject to review by the courts. ${ }^{30}$

A provision identical with that of the English law is found in the laws of Canada, Australia, New Zealand, and the Irish Free State.

While there is no statute with respect to compulsory licensing in the United States, other than the special provision in the Atomic Energy Act, ${ }^{31}$ there are a number of situations in which, in effect, compulsory licenses are granted. First, there is the right of the Government to use any patented invention with payment of compensation to the patentee. ${ }^{32}$ Second, there are some situations in which individuals are held free of liability under a patent, as in the case of intervening rights arising under reissued patents and the third-party rights protected by the Act making special provision for conditions arising from World War II. ${ }^{33}$ Third, the courts may, after finding a patent valid and infringed, nevertheless deny an injunction, thus permitting the defendant to continue using the invention, if the patentee can be compensated by money damages and if an injunction would be against the public interest or would unduly and adversely affect the defendant. ${ }^{34}$ Fourth, if the patentee has been misusing his patent the court may deny all relief, thus permitting the defendant and anyone else to use the invention without liability. Fifth, a court may, in a suit for violation of the antitrust laws involving patents, order the patentee to grant licenses to anyone who may apply, on payment of reasonable royalties. ${ }^{35}$

${ }^{30}$ Only two applications for licenses appear to have been made under this section: In the matter of Schou's Patents, $4 \mathrm{I}$ Rep. Pat. Cas. 298 (High Court, I924), (denied); Glazo Laboratories, Ltd., 58 Rep. Pat. Cas. 12 (Comptroller, 1940) (granted). The report referred to in note 19 recommended elimination of this provision from the law as being unnecessary in view of the other provisions with respect to compulsory licensing.

${ }^{31} 60$ StaT. 768,42 U. S. C. A. $\$ 18 \times 1$ (Supp. 1947).

${ }^{33} 36$ STAT. 85I (rgro), as amended, 35 U. S. C. $\$ 68$ (1940).

ss 60 STAT. $940,942,35$ U. S. C. \$\$10I and I03 (Supp. 1947).

st City of Milwaukee v. Activated Sludge, Inc., 69 F. 2 d 577 (C. C. A. 7th 1934).

${ }^{36}$ See Hartford-Empire Co. v. United States, 323 U. S. 386 ( $\times 945$ ), and United States v. National Lead Co., 332 U. S. 319 (1947). 


\title{
THE PATENT PROFESSION AND THE GENERAL LAWYER
}

\author{
Albert S. Davis, Jr.* and Harold T. Stowell
}

The term "patent profession" will be used in this discussion in a very broad sense to designate those professionally engaged in the legal aspects of the procuring and evaluation of patents. As thus used it includes several more or less readily distinguishable groups, which may be defined, possibly somewhat arbitrarily, as follows:

I. Lawyers principally engaged in patent litigation and problems ancillary to such litigation;

2. Lawyers principally engaged in the solicitation of patents and problems ancillary to such solicitation;

3. Non-lawyers engaged in the solicitation of patents and problems ancillary to such solicitation.

The term as used herein does not include a group which may be designated as "patent engineers," who typically are technically trained non-lawyers engaged, usually as employees of corporations, in acting as intermediaries and interpreters between the inventors and those directly engaged in soliciting or litigating patents, nor does it include "patent experts," who typically are technically trained non-lawyers engaged, usually on a per diem basis for a particular case, in assisting with the technical-legal problems arising in patent litigation, and occasionally also in patent solicitation.

The first two groups listed above may be designated jointly as "the patent bar." It would be unrealistic to consider these as sharply distinguished groups analogous to the barristers and solicitors of the English system. All of the lawyers engaged in the solicitation of patents may, and many, if not most, of them do, at least occasionally, participate in patent litigation, either as principal or as associate counsel. On the other hand, most lawyers engaged principally in patent litigation are associated with firms which handle the solicitation of patents and are, at least occasionally, consulted in the problems arising in such solicitation. This lack of sharp dichotomy between those engaged in patent litigation and those engaged in patent solicitation is highly desirable, as it clearly tends to improve the soundness and strength of the

-A.B. 1933, Bowdoin College; LL.B. 1936, Yale University. Member of the New York bar; Resident Attorney, Research Corporation; Adjunct Professor of Administrative Engineering, New York -University, since 1945. Contributor to legal periodicals.

TLL.B. 1930, M.P.L. 1930, Washington College of Law. Member of the District of Columbia and patent bars; formerly Lecturer on Federal Jurisdiction and Procedure, and Patent Contracts, Washington College of Law. 
patents obtained if those engaged in solicitation have a continual direct contact with the difficulties and problems arising in patent litigation.

It may be contended that the exclusion of "patent engineers" and "patent experts" from the scope of the term "patent profession" is arbitrary, and we would not quarrel with those who would include these groups in that term. Certainly neither group can eliminate the legal aspects from the problems on which they are engaged. Their opinions and their advice, even though based on scientific or technical data, would have little value in many cases if those rendering the opinion or advice were not intelligently aware of the legal background in which the opinion or advice is to be used. In fact, it must be acknowledged that many experienced patent experts discuss the legal aspects of such questions as anticipation and infringement on at least an even footing with skilled members of the patent bar.

On the other hand, we feel that there are many lawyers who would quarrel with our inclusion of the group of non-lawyer patent solicitors in the term "patent profession," and to this issue we must devote more detailed consideration as it is an issue with a considerable background and of substantial importance. As to the questions raised by this issue we wish to express a hope and an opinion: the hope that the questions will not be answered arbitrarily or on the basis of emotion-charged catch-phrases, and the opinion that the questions are in process of being answered rationally by a combination of intelligent administrative policy in the Patent Office and the inevitable effects of the trend towards increased specialization. To be specific, we believe that the patent solicitor of the not-too-distant future will be required to be, as the typical patent solicitor of today increasingly is, equipped with both an adequate technical training and an adequate legal training. The steady trend toward a more rigorous standard of qualification for enrollment in specialized and administrative practice bars is not peculiar to the patent profession, but is a widely occurring development ranging all the way from Treasury representation to the federal district courts.

The Commissioner of Patents has long had the authority" to "prescribe rules and regulations" for the recognition of persons representing applicants and other parties before the Patent Office, and to exclude from practice before the Office any person shown to be incompetent, disreputable, or guilty of gross misconduct. Prior to 1934 admission to the register of "attorneys" was granted upon written request accompanied by a showing that the applicant possessed "the necessary legal and technical qualifications to enable him to render applicants for patents valuable service." Normally the Commissioner required a showing of a period of practice in preparing and prosecuting applications for patent under the supervision of a registered patent attorney or, in lieu thereof, a sufficient period as a member of the examining corps of the Patent Office.

In 1934 the Commissioner of Patents inaugurated the examination system for determining whether applicants for registration as patent attorneys possessed "the

${ }^{2}$ Rev. Stat. $\$ 487$ (1875), 35 U. S. C. \$II (1940). 
necessary legal and scientific qualifications." These examinations are conducted under the auspices of the Civil Service Commission. They are by no means perfunctory: of sixty-one candidates taking the first examination, only seventeen passed. It is understood that the proportion passing subsequent examinations has been somewhat higher, which is probably due to more serious preparation on the part of the candidates. ${ }^{2}$

Since November, I938, a distinction has been made on the Patent Office register between lawyers and non-lawyers, the former now being enrolled as "attorneys" and the latter as "agents."

Perennial attempts have been made, continuing to the current session of Congress, to obtain the passage of legislation which would restrict all practice before the Patent Office to members of the general bar, or alternatively would admit all members of the general bar to such practice without further qualification. It is the considered opinion of the writers that both of these proposals are unsound. Nonlawyer patent attorneys have a long and honorable record of service to inventors seeking patents on their inventions. Typically, they bring to this service a background of scientific and technical training and experience which is invaluable to their clients. The recurring proposals to bar such individuals from further service in their profession are repugnant to American principles, and it is not believed that Congress will accede to them. Nevertheless a time will probably come, through the natural processes of selection and evolution, when further enrollment on the register of those entitled to practice before the Patent Office may be restricted fairly and properly to lawyers who possess the necessary scientific qualifications "to render applicants for patents valuable service."

The trend toward an eventual Patent Office register limited to lawyers is clearly indicated by the character of recent enrollments. In the three successive three-year periods since lawyers and non-lawyers were first separated on the register, the pro. portion of lawyers among those enrolled has been 47 per cent, 52.5 per cent and 57.5 per cent. ${ }^{3}$ This steady and substantial increase in the proportion of lawyers is significant, and indicates an evolution in a desirable direction.

The control exercised by the Commissioner of Patents over the methods of practice and the actions of patent attorneys has been persistent and, when occasion has demanded, vigorous. ${ }^{4}$ The cited case illustrates the disbarment procedure in the Patent Office under existing statutes. Without belaboring the much-debated question of the advertising agent as against the non-advertising attorney, we believe that both the means of preventing and correcting any possible abuses, and a willingness to do so, are apparent.

The training of the patent profession in the special techniques and peculiar problems presented by patents and inventions is commonly obtained today by

${ }^{2}$ Questions from the first of these examinations were reproduced in I7 J. PAr. Opp. Soc'r 259-26r (1935).

3 Based upon annual registrations of attorneys and agents, r939-1947.

'Hatch v. Ooms, 69 F. Supp. 688, 72 U. S. P. Q. 405 (D. D. C. 1947). 
actual practice in the offices of patent lawyers, in the patent departments of the larger corporations, or in service as a member of the examining corps of the Patent Office. Academic courses in the law schools, in general, do not in point of fact offer much in the way of specialized training for this profession. The curriculum for the specialist in patent law should include such courses as substantive patent law, Patent Office practice (with patent interference practice preferably treated in a separate course), trade marks and unfair competition, copyright law, patent contracts (it cannot be assumed that the law school course in contract law is in any sense an adequate preparation for the drafting and interpretation of contracts and agreements relating to patents), and patent litigation (including declaratory judgment procedure, which is today a substantial branch of the law of patents).

As a matter of fact, however, the courses in patent law subjects offered in most law schools today would be of more ultimate value to the prospective general lawyer, who rarely elects to take them, than to the prospective patent specialist. The patent specialist gets his patent law training elsewhere; the general lawyer, unfortunately, does not even get an adequate understanding of the basic special principles necessary properly to advise his clients in situations involving patents and inventions. In general, he feels lucky if he knows of a patent lawyer to whom he can turn for counsel in such a situation, or to whom he can refer the matter.

When presented by his client with a memorandum of invention requiring patent protection, the general lawyer will refer the case to a member of the patent bar. The rules force him to do so, even if good judgment would not. Only a minority of patent matters, however, involve the actual prosecution of patent applications or even a decision on whether to file. Indeed, it may be said properly that a good deal of the art of patent practice depends on ability to decide when a knowledge of substantive patent law is required. It is in that precise zone of decision that legal representation can be most useful, and is often most deficient.

Much of the practice of a young lawyer in his own office, for instance, consists of organizing small, closed corporations. A surprising number of these corporations plan to go into "kitchen-sink" manufacturing, rather than retailing, wholesaling, or the service trades, for the tradition of the Yankee inventor is still strong with us. It follows in many cases that the availability of patent protection (and its proper contractual safeguarding and management) is such a corporation's strongest point, for it cannot compete with established rivals on the score of established customer lists, sales and promotion budgets and personnel, or distribution techniques. Save in the rarest cases, such a young lawyer cannot give competent advice as to the preservation, enlargement, and management of a patent property. In the rare event that he has taken a law school course in patent law, it will for the main part have been confined to patentability and procedural matters; and even in the unlikely event that it has involved management matters, it cannot possibly have given him negotiative experience.

Now this difficulty is not at all 'confined to' such representation. The average 
well-established law firm in our larger cities, with four or five partners and a halfdozen associates and clerks, usually boasts a "horse-trader" of some deserved reputation. Negotiations involving applied patent law, however, are just as likely as not to involve the trading of zebras. In five years, for instance, such a firm might have presented to it typically the drafting of a contract for the acquisition of apparatus using materials compounded and renewed from time to time by a secret process where the vendee may service the apparatus it buys but must preserve the secret; reporting for foreign funds control and the alien property custodian of domestic and foreign patents, applications, and contracts relating to them; merger of a corporation manufacturing a patented article which is involved in a chain of defensive and aggressive infringement suits; bankruptcy of a corporation whose entrepreneur has put into it patents to which he has tied a string; a client's wish to go into the business of manufacturing a game which is only debatably patentable but should have great novelty impact; a half dozen sales-contract and purchase-order forms with differing patent indemnity clauses; and an intestate estate in which the principal assets are a patent application and a memorandum of invention. Each of these, for efficient disposition, would require adequate knowledge of substantive patent law.

How will they be dealt with in ordinary routine? The majority of the firms presented with them will educate a partner, more or less hastily, in the broader legal implications of the situation at hand, and in addition will probably see to it that an associate spends a good deal of time deciding what points are likely to be of importance and on what considerations they may turn. Examination of case law or treatises such as Corpus Juris is of little help; instead, principal reliance will be placed on textbooks such as Ridsdale Ellis' Patent Assignments and Licenses, or nonlegal materials such as Berle and de Camp's Inventions and Their Management. This, of course, does not mean that any competent general attorney is going to be guilty of such a legal howler as imagining that assignment of an undivided one-third interest in a patent saddles the assignee with the duty of accounting for one-third of his profits. It suggests very strongly certain weaknesses in many directions, however. As an example, consider the problems implicit in the need of selection among (a) minimum royalties, (b) a simple due-diligence clause, (c) a requirement of investing and keeping invested a certain amount of capital, (d) a men-money-time clause, or (e) a requirement that $\mathrm{X}$ units for $\mathrm{Y}$ months be produced, as alternative means of preventing shelving, assuring production, and securing royalties. The problem is even more apparent in cases involving negotiations more dependent on peculiar and fluxing rules of law, such as licensees' covenants to respect validity.

The other alternative open to the general lawyer on negotiative and management matters is to consult with or forward to a patent specialist. Putting aside the fact that it is usually somewhat more expensive for the client thus to be doubly represented, there is always something lost in an attempt so to transmit the subtler nuances of a client's wishes. Again, should drafting and negotiations be taken over by the patent specialist in direct collaboration with the client, much of value, that the 
general lawyer is in an unusually good position to contribute from his own fund of corporation, tax, and contract experience, may be sacrificed.

Still another facet of the problem is presented by the patent specialist himself. Many members of the patent profession, of course, tend far more to be experts in soliciting-the procedural and Office techniques of prosecution-than in what, for want of a better phrase, might be called applied commercial patent law. Within the last year the president of a large corporation whose competitive advantages and commercial position are largely dependent on patent protection, licensing, and being licensed by others, commented to one of the writers that his patent department was unskilled in the realities of negotiation, though unusually apt in prosecutions.

There is, of course, nothing new in pointing to the fact that the most serious deficiency in young attorneys is lack of practical experience. It has plagued the bar, the law school, and the client alike since the substitution of the law school for the apprentice system of "reading law." When we turn to any field complicated by the incidence of special substantive law, whether it be patents, admiralty, or administrative law, the difficulty is emphasized. What sets aside the field of applied patent law as unusually perplexing, however, is that it commonly brings within its scope a great number and variety of clients having little knowledge or appreciation of the day-to-day impact upon them of its legal effects. In admiralty, for instance, the client is likely to accept the law peculiar to him from common knowledge in his special field of business. The average man or company affected by the patent law learns of it, in most cases, only when he is forced to. For that reason, the patent lawyer, in negotiative matters, has a rather heavy burden to bear.

The skilled patent lawyer, then, may well see fit to educate his client to some extent in the general philosophy of patent law. But quis ipsos ...?

How can the general lawyer be trained to an understanding of the special substantive law of patents which will be useful to him and his client? How can he acquire negotiative skills based on that understanding? And is such double training likely to be a sufficient answer to the larger problem?

To deal with the last question first, it is not too easy to see on a pragmatic basis any sound objections to such training, if it can be adequately accomplished. It is over-ingenuous to argue that the general lawyer will, after picking up a smattering of knowledge, sacrifice his client's interests by relying too much on his own untested resources. If he is of such a temperament, he will make the blunder anyway on the basis of a bookshelf. He cannot forever have the skilled patent lawyer in close association with him, and some questions demand an answer without reference. A client accepting a lucrative rush purchase order with a twenty-line fine print clause on the reverse headed "Patent Indemnity" is in no mood to be told that an answer will be sought by long-distance. Yet if the client goes to the patent lawyer in the first instance there is a substantial possibility that he will miss what assistance the general lawyer could give him from his own fund of specialized knowledge, or fail to combine the two threads of counsel properly. 
As has been intimated, the problem of such special training is not peculiar to patent law. All application of legal knowledge, what one may call the task of the counselor rather than the attorney, is and must be on the ground of experience.

Does the answer lie with the law schools?

In other fields, notably in corporation law, pleading, and appellate practice, the law schools have struggled to give their students more than an academic knowledge of legal rules. Justice Douglas' and Professor Foster's classes in "Business Units," and Judge Arnold's "Judicial Process," both at Yale, are excellent examples, in widely divergent studies, of successful attempts to develop the strategic and evaluative techniques of law from an examination of their factual application. Such attempts necessarily remained one step away from the brutal need and nervous factual impact of actually making decisions; they rather showed how and why decisions were made. Moot court work, whether appellate or trial, is a time-honored method of letting the student reproduce his future activity. More lately the law schools have got down to actual cases and by collaboration with legal aid societies and practicing lawyers have started to give back to the student the apprenticeship lost so long in the emphasis on the case system of instruction and the replacing of required clerkship by the earning of a degree in law.

It is most unlikely, however, that the law school curriculum has more than a slight chance of being adapted to such training purposes. The combination of instruction in the standard subjects, practical courses in applied law such as those dealing with corporate reorganization, training of a less academic flavor, and cramming for and against bar examinations (including local practice courses) simply does not leave enough time, for one thing. For another, not one student in twenty has the slightest intimation that he will ever have anything to do with patents. Patent law, even Patent Office patent law, seems fated to remain a curricular step-child, like municipal corporations and international law, in most law schools.

But beyond and above this is the sheer difficulty of obtaining the necessary clinical case material on the practical level. What we are concerned with is analyzing business situations involving patent matters and requiring the selection of one of several decisions. Applied law available to the student usually deals with small stuff. No executive with major responsibilities is particularly anxious or even willing to admit students to the arcana of his business deliberations. Even if names and overrevelatory facts are omitted or disguised and the cases taken at second-hand, the patent attorney will feel substantial compunction against disclosing what is going on in his client's affairs, and especially those neat points and equilibrations on which his decisions will turn. Except in our larger cities, patent attorneys are not overnumerous, and those who have had broad negotiative experience are relatively rare. Finally, the law student usually lacks the general foundation of business or applied legal experience which is the basis necessary for training in any more specialized field involving negotiative techniques. 
A somewhat different picture results when such a course is presented on the graduate level. Something may be said for a substantial attempt to enlist nonlawyers among the students, or to present it in the school of engineering, technology or business administration. Unhappily, the substantially valuable experience and comment which are then added from the side of the businessman, the technician or the inventor, are often counterbalanced by the necessity of spending too much time along the way educating them in the legal minima which are really side-issues in patent deliberations. One or the other of us, for instance, in his experience with such courses, has found himself diverted to attempting hurried outlines of the law of bilateral as against unilateral contracts, implied agency, declaratory judgments, and questions arising from express as distinguished from implied warranties of title. It must be frankly admitted that as yet no academic graduate course in applied patent law is or seems likely soon to be in a position to pick its students on a basis of anything but mental ability, and it is highly questionable whether selection on any other grounds would not largely defeat the very purpose of such a course. Yet a course of such scope is likely to get into the difficulties implicit in attempting to be all things to all men.

The last and most promising possibility is the professional seminar or clinic, in which such strides have been made by the Practising Law Institute during the last few years. Here the basic idea has been to make available to the lawyer the experience of specialists in various fields, directed towards the broader philosophy of the speciality, the cogent turning points in it which are more commonly of importance to the non-specialist who is pitchforked into the field, and recent developments which are apt to change the recognized criteria of consideration and decision. More recently the emphasis on and value of such seminars in general has been given tremendous impetus by the correlated development of veterans' refresher courses. Thus far all such work has tended largely in two direction: bread-and-butter lines singularly subject to know-how, such as title reading and probate practice, and such rapidly expanding or shifting fields as administrative law, income taxes, and labor relations.

The Practising Law Institute of New York has, however, actually presented some more or less exploratory courses in applied patent law with what seemed to be favorable results.

The most obvious advantage of such a seminar, of course, is that is is primarily composed of mature lawyers who not only realize the professional doubts and diffculties which have led them to take it, but possess sufficient experience to fit it into their day-to-day routine. The atmosphere of master and student can be arrested almost entirely, and where the attendant is as capable as the lecturer of contributing factual situations for analysis and suggestion, the whole examination of the law "gets down to cases" a lot more quickly than would be possible in any other intellectual climate. Again, the average member of such a seminar will be in the habit of handling fresh situations by the application of past actual experience, and will there- 
fore be in a position to project the seminar's conclusions into future useful application.

It is rather out of character, in speaking of the possible content of such a seminar, to talk of "courses." The subject matter, however, should in our opinion differ rather widely from what we have suggested as a proper educational background for entry into the patent profession. In the first place, only the broadest outline of the technique and procedure of Patent Office practice is necessary. While some time can be devoted profitably to the theory of claim reading and dominating-dominated coverage situations, such material as technical patentability, the semantics of claim drawing, Markush and genus-species practice, and sub-combination claims may also well be ignored. Instead, once the general idea of what a patent solicitor tries to do has been implanted, the seminar could more profitably consider the trade secret and its interrelation with the legalistic protection afforded by a patent, largely developed through the trade secret's own legal weakness. This in turn would lead into consideration of the weaknesses of patent protection, both in the light of recent politico-economic trends, and as an adjunct of over-patenting and over-manipulation for various reasons, good or bad, of the essentially simple monopoly which is the classic and intended core of the patent.

The real meat of such a seminar, however, as we have already indicated, would be a broad study of the various types of agreements by which patents are protected or bartered away (depending on what terminology one chooses to apply), followed by more detailed examination of their commercial incidents. We would suggest that this examination not proceed seriatim through the catalogue of license clauses-preamble, licensed patent, licensing clause, royalty, and the like-but rather on a basis of "Here is John Doe, with a patent on a cheap, efficient carpetsweeper. He plans to license it exclusively to a manufacturing company, formed for that purpose by 2 parent corporation of a rather speculative character whose primary experience has been in merchandising packaged apparatus put together from sub-assemblies. What does he have to worry about, and what protective steps should he take? At what points should he give a little; where should he stand firm?"

If the seminar lecturer is adroit, one or two discussions along these lines will open the floodgates to a spate of the members' actual and anticipated problems. There are certain difficulties in this, of course, for nothing is so discouraging as meeting the "free rider" who is glad to have a consultation without the pain of paying a fee. Proper management can avert this, however, and the presentation of actual problems is certainly the most useful method of getting to the heart of the subject.

Assuming that the seminar ever gets past this point, in its allotted span of evenings (and in all seriousness it is not too likely to), it might then turn to the growing field of patent relations between the government and the patent-holder or licensee, for government contract patent clauses, royalty agreements and unofficial 
renegotiations, and even international patent relations are still of cogent importance in our scheme of things, despite the cessation of actual hostilities.

Such a program possesses sufficient flexibility to adapt it to the uses of the bar in almost every locality having a local bar association or even an interested group of general lawyers.

It will not, of course, create another branch of the patent profession-it will not even materially reduce references and special retainers where they are really called for. On this score, we need only as an example point to the immensely complicated negotiative situation where a patent or application which must be licensed is involved in an interference or is seriously dominated. On the other hand, we feel that it offers the best hope of bringing home to the general lawyer a very real and widely unrecognized set of professional responsibilities. 